\title{
Analysis of serum levels of titanium and aluminium ions in patients with early onset scoliosis operated upon using the magnetic growing rod-a single centre study of 14 patients
}

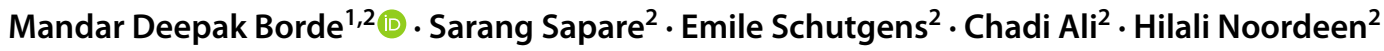

Received: 18 December 2019 / Accepted: 15 March 2021 / Published online: 23 July 2021

(c) Crown 2021

\begin{abstract}
Study design A cross-sectional retrospective Level 3 study.

Objective To study the serum levels of Titanium and Aluminium ions in patients operated using the magnetically controlled growing rod (MCGR) system.

Summary of background data 14 consecutive patients of early onset scoliosis with varying etiology managed with MCGR system with a minimum follow-up of 24 months were selected for the study. The group consisted of two boys (14.3\%) and 12 girls $(85.7 \%)$. The average age of the patients at the time of surgery was 10.4 years (5-15 years). The average period of follow-up was 43.7 months (28-79 months). After informed consent of the subjects and their caretakers, serum levels of titanium and aluminium were measured. These levels were then assessed with regards to the number of screws used, number of distractions and complications.

Methods The concentration of titanium and aluminium ions in the serum was measured using high resolution inductively coupled plasma mass spectrometry.

Results For the sake of ease of assessment, patients were divided into three etiology-based groups-idiopathic $(n=6)$, neuromuscular $(n=2)$ and syndromic $(n=6)$. The mean serum titanium level was $15.9 \mu \mathrm{g} / \mathrm{L}(5.1-28.2 \mu \mathrm{g} / \mathrm{L})$ while that of aluminium was $0.1 \mu \mathrm{mol} / \mathrm{L}(0.1-0.2 \mu \mathrm{mol} / \mathrm{L})$. Of the 14 patients, $2(14.2 \%)$ patients had mechanical failure (actuator pin dysfunction), 3 (21.4\%) had rod breakage requiring revision surgery and one patient (7.1\%) had surgical site infection managed with appropriate antibiotics. Patients undergoing revision for rod breakage did not show any metallosis of the tissues during surgery.

Conclusion Analysis of patients with scoliosis operated using the magnetic growing rod system concludes that it is accompanied by presence of titanium in the blood but whether clinically significant or not needs to be ascertained by comparison of preoperative and postoperative blood concentrations of the titanium ions in individual subjects. The aluminium ion concentration remains within normal limits. Though implant malfunction may raise the titanium levels in the blood, its clinical significance needs to be determined. The aluminium levels are not affected irrespective to the presence or absence of complications. The long-term effects of raised titanium levels in the blood also warrant further prospective studies designed for precise and deeper analyses.
\end{abstract}

Keywords Early onset scoliosis · MCGR $\cdot$ Serum levels $\cdot$ Titanium ions · Aluminium ions

Mandar Deepak Borde mandarborde@gmail.com

Hilali Noordeen

hilali.noordeen@nhs.net

Sarang Sapare

sarang.sapare@gmail.com

Emile Schutgens

eschutgens@live.nl
Chadi Ali

chadi.ali1@nhs.net

1 Department of Orthopaedics and Spine Surgery, Bharati Vidyapeeth (Deemed to be University) Medical College, Pune-Satara Road, Dhankawdi, Pune, Maharashtra 411043, India

2 Department of Spine Surgery, Royal National Orthopaedic Hospital, Stanmore, Middlesex, UK 


\section{Introduction}

The treatment of early onset spinal deformities has consistently posed a challenge to the spinal surgeons for a long time. The advent of fusionless instrumentation that allows spine growth in addition to arresting the progression of deformity in cases with high growth potential has helped avoid early fusion surgery in paediatric patients. Growing rods (GR) act as temporary internal braces that allow the growth of the spine, lungs and the thoracic cage while controlling the deformity. These growing rods can be mechanically or magnetically extended $[1,2]$. These growing rods require intermittent extension (atleast twice or thrice yearly). The magnetically extendable growing rods allow a non-invasive method of extension as compared to the mechanically extendable ones.

As these rods slide in the guiding fixtures, they have a potential to generate excessive metallic debris (metallosis). Metal ion release has been addressed in adolescent idiopathic scoliosis (AIS) literature. Localized metal debris has been well documented in the paraspinal soft tissues surrounding instruments [3]. Elevated levels of titanium (Ti) ion in the blood and its systemic distribution via blood and lymphatic vessels and distant organ settlement of particulate debris have also been demonstrated [4-6]. A case report identifying wear debris-induced osteolysis around a pedicle screw after posterior spine fusion in a pediatric patient has also been reported [7].

When compared to instrumented spinal fusion for AIS, GR applications comprise fewer implants but they are more frequently manipulated. Therefore, although the dose and mode may vary, logically thinking, children with early onset deformities treated with growing rods should also be subjected to metallic exposure. Yet, very less research has focused on metal-ion release and distribution in growth friendly instrumentation for early-onset scoliosis (EOS). Also, the clinical effects of the raised metal ion levels in children are yet to be determined. The aim of this study was to measure the content of titanium and aluminium ions in the blood of patients having high growth potential and treated with magnetically controlled growing rod (MCGR) system.

\section{Material and methods}

\section{Study design and participants}

This was a single centre, cross-sectional retrospective study. Fourteen consecutive patients (two boys and 12 girls) with early-onset scoliosis attending the Spine
Deformity Clinic with an average age of 10.4 years (5-15 years) at the time of surgery and treated with magnetically controlled growing rod (MCGR) system during the period from 2010 to 2017 with a minimum postoperative follow-up of 24 months were recruited in the study group. The average time between the index surgery and the time the blood was drawn was 43.7 months (28-79). The subjects comprised of six patients with idiopathic scoliosis, two patients with neuromuscular scoliosis and six patients with syndromic scoliosis (Table 1). Of the 14 patients, patients with Cerebral palsy and those with Prader Wili syndrome, Andersen Tawil syndrome and Rett syndrome were unable to ambulate independently due to their primary syndromic condition. The remaining nine patients were independent ambulators. Twelve patients were implanted with the first generation MCGR while two received the newer generation rod. All patients underwent a dual rod construct. A total number of 111 screws were used at the anchor points with 7.9 screws per construct (range 6-11) (Table 2).

The patients underwent a total of 75 distractions with an average of 5.3 distractions per patient (range 2-9) (Table 2) at 3-month intervals in the outpatient department during their regular follow-up.

The study was approved by the Institutional Ethical Committee.

\section{Collection and analysis of specimens}

The MCGR comprises of Ti-6Al-4 V ASTM F136 titanium alloy.

After appropriate consent of the subjects and their care takers, venous blood samples were collected after the lengthening procedure during the regular follow-up. The serum titanium and aluminium levels were measured using highresolution inductively coupled plasma mass spectrometry.

$5 \mathrm{~mL}$ of blood were collected into Vacuette ${ }^{\circledR}$ Trace Elements tubes (Greiner Bio-One International) coated with sodium heparin as anticoagulant. The samples were refrigerated at $4{ }^{\circ} \mathrm{C}$ prior to analysis. Samples were analysed for titanium and aluminium content on a Thermo Element $2 \mathrm{~h} \mathrm{ICP-}$ MS instrument (Thermo Fisher Scientific GmBH, Bremen, Germany). $150 \mu \mathrm{L}$ of each sample were dispensed into polystyrene assay tubes with $150 \mu \mathrm{L}$ of water and $4.5 \mathrm{~mL}$ of assay diluent $(0.5 \%(\mathrm{v} / \mathrm{v})$ tetramethylammonium hydroxide (Electronics grade, Alpha Aesar, US), 0.005\% (v/v) Triton $\mathrm{X}-100$ (Romil, UK)) and $2.5 \mu \mathrm{g} / \mathrm{L}$ gallium (Alpha Aesar, US). Calibration standards were prepared by dilution from a custom stock solution (Qmx Laboratories Limited, Thaxted, UK) with a titanium and aluminium concentration traceable to NIST SRM 3162a Lot 130,925. The standard concentrations were: $0.00,1.00,4.00,9.99,39.96,99.90$ and $249.75 \mu \mathrm{g} \mathrm{L}^{-1}$. Serum matrix matched calibrations were 
Table 1 Table depicts the demographic and etiological details with the serum concentrations of the titanium and aluminium ions of all the subjects

\begin{tabular}{|c|c|c|c|c|c|c|c|c|c|}
\hline $\begin{array}{l}\text { Patient } \\
\text { number }\end{array}$ & Gender & $\begin{array}{l}\text { Age at } \\
\text { Surgery } \\
\text { (years) }\end{array}$ & $\begin{array}{l}\text { Duration of } \\
\text { blood test } \\
\text { since surgery } \\
\text { (months) }\end{array}$ & $\begin{array}{l}\text { Pre op coronal } \\
\text { Cobb angle } \\
\text { (degrees) }\end{array}$ & $\begin{array}{l}\text { Pre op sagittal } \\
\text { Cobb angle } \\
\text { (degrees) }\end{array}$ & $\begin{array}{l}\text { Length } \\
\text { achieved at } \\
\text { the end of all } \\
\text { lengthnings } \\
(\mathrm{mm})\end{array}$ & Etiology & $\begin{array}{l}\text { Titanium } \\
(\mu \mathrm{g} / \mathrm{L})\end{array}$ & $\begin{array}{l}\text { Aluminium } \\
(\mu \mathrm{mol} / \mathrm{L})\end{array}$ \\
\hline 1 & M & 5 & 38 & 78 & 77 & 17.8 & $\begin{array}{l}\text { Sotos syn- } \\
\text { drome }\end{array}$ & 14.9 & 0.2 \\
\hline 2 & F & 11 & 44 & 96 & 84 & 15.7 & Rett syndrome & 25.6 & 0.1 \\
\hline 3 & $\mathrm{~F}$ & 13 & 39 & 55 & 35 & 10.5 & Idiopathic & 5.0 & 0.1 \\
\hline 4 & F & 11 & 29 & 93 & 25 & 10.5 & Idiopathic & 10.3 & 0.1 \\
\hline 5 & F & 13 & 28 & 98 & 45 & 22.7 & $\begin{array}{l}\text { Pterygium } \\
\text { syndrome }\end{array}$ & 28.2 & 0.1 \\
\hline 6 & $\mathrm{~F}$ & 15 & 31 & 86 & 70 & 5 & Cerebral Palsy & 19.7 & 0.2 \\
\hline 7 & M & 7 & 79 & 95 & 38 & 48.1 & $\begin{array}{c}\text { Prader Willi } \\
\text { syndrome }\end{array}$ & 14.5 & 0.2 \\
\hline 8 & $\mathrm{~F}$ & 12 & 40 & 70 & 24 & 90 & $\begin{array}{l}\text { Andersen } \\
\text { Tawil syn- } \\
\text { drome }\end{array}$ & 9.9 & 0.2 \\
\hline 9 & $\mathrm{~F}$ & 12 & 40 & 66 & 28 & 48.2 & Idiopathic & 13.1 & 0.2 \\
\hline 10 & $\mathrm{~F}$ & 7 & 60 & 87 & 47 & 49.5 & Idiopathic & 20.6 & 0.1 \\
\hline 11 & $\mathrm{~F}$ & 10 & 48 & 70 & 44 & 18.3 & Cerebral Palsy & 14.5 & 0.2 \\
\hline 12 & $\mathrm{~F}$ & 9 & 48 & 72 & 30 & 55.6 & Idiopathic & 12.7 & 0.2 \\
\hline 13 & $\mathrm{~F}$ & 12 & 40 & 65 & 42 & 16.8 & $\begin{array}{l}\text { Neurofibroma- } \\
\text { tosis } 1\end{array}$ & 18.7 & 0.1 \\
\hline 14 & $\mathrm{~F}$ & 9 & 48 & 55 & 16 & 22.5 & Idiopathic & 15.3 & 0.1 \\
\hline
\end{tabular}

Table 2 Table depicting the number of screws per construct with the number of distractions and the corresponding serum levels of titanium and aluminium

\begin{tabular}{lcllll}
\hline $\begin{array}{l}\text { Patient } \\
\text { number }\end{array}$ & $\begin{array}{l}\text { Number of screws } \\
\text { per construct }\end{array}$ & $\begin{array}{l}\text { Number of } \\
\text { distractions }\end{array}$ & Complications & $\begin{array}{l}\text { Titanium } \\
\text { levels }(\mu \mathrm{g} / \mathrm{L})\end{array}$ & $\begin{array}{l}\text { Aluminium } \\
\text { levels } \\
(\mu \mathrm{mol} / \mathrm{L})\end{array}$ \\
\hline 1 & 8 & 8 & Rod breakage & 14.9 & 0.2 \\
2 & 10 & 4 & Actuator pin dysfunction & 25.6 & 0.1 \\
3 & 8 & 2 & None & 5.0 & 0.1 \\
4 & 6 & 7 & None & 10.3 & 0.1 \\
5 & 10 & 6 & Surgical site infection & 28.2 & 0.1 \\
6 & 11 & 4 & Rod breakage & 19.7 & 0.2 \\
7 & 8 & 5 & Actuator pin dysfunction & 14.5 & 0.2 \\
8 & 8 & 4 & None & 9.9 & 0.2 \\
9 & 6 & 6 & None & 13.2 & 0.2 \\
10 & 6 & 9 & Rod breakage & 20.6 & 0.1 \\
11 & 8 & 9 & None & 14.5 & 0.2 \\
12 & 8 & 6 & None & 12.7 & 0.2 \\
13 & 6 & 7 & None & 18.7 & 0.1 \\
14 & 8 & 9 & None & 15.3 & 0.1 \\
\hline
\end{tabular}

prepared by dispensing $150 \mu \mathrm{L}$ of each standard into polystyrene assay tubes with $4.5 \mathrm{~mL}$ of assay diluent and $150 \mu \mathrm{L}$ and either Defibrinated Horse Blood (TSC Biosciences, Buckingham, UK) or Foetal Bovine Serum (Sigma-Aldrich, UK).

\section{Statistical methods}

The mean value of the titanium and aluminium ions concentrations were calculated. There is no universally accepted minimum and maximum range of serum levels of titanium 
ions in the paediatric population. The range of serum aluminium level quoted by the institutional laboratory was $0-0.4 \mu \mathrm{mol} / \mathrm{L}$. The patients were divided into three groups based on their etiology of idiopathic $(n=6)$, neuromuscular $(n=2)$ and syndromic $(n=6)$ (Table 3$)$ for the ease of assessment. In addition, patients with and without any complications were divided into two groups.

\section{Results}

The mean serum titanium levels were $15.9 \mu \mathrm{g} / \mathrm{L}(5.1-28.3)$ while that for aluminium were $0.1 \mu \mathrm{mol} / \mathrm{L}(0.1-0.2)$. The mean titanium levels of the idiopathic, neuromuscular and syndromic groups were $12.9 \mu \mathrm{g} / \mathrm{L}(5.1-20.6) ; 17.1 \mu \mathrm{g} / \mathrm{L}$ (14.5-19.7) and $18.6 \mu \mathrm{g} / \mathrm{L}$ (9.9-28.2), respectively, while those for aluminium were $0.1 \mu \mathrm{mol} / \mathrm{L}(0.1-0.2) ; 0.2 \mu \mathrm{mol} / \mathrm{L}$ $(0.2-0.2)$ and $0.1 \mu \mathrm{mol} / \mathrm{L}(0.1-0.2)$, respectively (Table 3$)$. In the idiopathic group $(n=6)$, one patient had to undergo a revision surgery for a rod breakage (titanium level $20.6 \mu \mathrm{g} / \mathrm{L}$; aluminium level $0.11 \mu \mathrm{mol} / \mathrm{L}$ ). The neuromuscular group $(n=2)$ comprised of cerebral palsy patients. One of these patients underwent a revision surgery for a rod breakage (titanium level $19.7 \mu \mathrm{g} / \mathrm{L}$; aluminium level $0.2 \mu \mathrm{mol} / \mathrm{L})$. The syndromic group $(n=6)$ comprised one patient each of Sotos syndrome (SS), Rett syndrome (RS), Prader Willi syndrome (PWS), Neurofibromatosis 1 (NF1), Andersen Tawil syndrome (ATS) and Pterygium syndrome (PS). Of these, patients with RS (titanium level $25.6 \mu \mathrm{g} / \mathrm{L}$;

Table 3 Etiology wise distribution of the serum titanium and aluminium levels

\begin{tabular}{lcl}
\hline Patient number & $\begin{array}{l}\text { Titanium level } \\
(\mu \mathrm{g} / \mathrm{L})\end{array}$ & $\begin{array}{l}\text { Aluminium } \\
\text { level }(\mu \mathrm{mol} / \mathrm{L})\end{array}$ \\
\hline Idiopathic group & & \\
3 & 5.0 & 0.1 \\
4 & 10.3 & 0.1 \\
9 & 13.1 & 0.2 \\
10 & 20.6 & 0.1 \\
12 & 12.7 & 0.2 \\
14 & 15.3 & 0.1 \\
Neuromuscular group & & \\
6 & 19.7 & 0.2 \\
11 & 14.5 & 0.2 \\
Syndromic group & & \\
1 & 14.9 & 0.2 \\
2 & 25.6 & 0.1 \\
5 & 28.2 & 0.1 \\
7 & 14.5 & 0.2 \\
8 & 9.9 & 0.2 \\
13 & 18.7 & 0.1 \\
\hline
\end{tabular}

aluminium level $0.1 \mu \mathrm{mol} / \mathrm{L}$ ) and PWS (titanium level 14.5 $\mu \mathrm{g} / \mathrm{L}$; aluminium level $0.2 \mathrm{umol} / \mathrm{L}$ ) suffered mechanical failure in the form of actuator pin dysfunction; patient with PS (titanium level $28.2 \mu \mathrm{g} / \mathrm{L}$; aluminium level $0.1 \mu \mathrm{mol} / \mathrm{L}$ ) had a surgical site infection managed with appropriate antibiotics and the SS patient (titanium level $14.9 \mu \mathrm{g} / \mathrm{L}$; aluminium level $0.2 \mu \mathrm{mol} / \mathrm{L}$ ) suffered rod breakage warranting revision surgery. The mean serum titanium level of patients experiencing complications was $20.6 \mu \mathrm{g} / \mathrm{L}(14.5-28.2)$ which was higher than the mean level of those without any complications $12.5 \mu \mathrm{g} / \mathrm{L}$ (5.0-18.7). The mean serum levels of patients experiencing complications and those without were almost the same ( 15.4 and $15.3 \mu \mathrm{mol} / \mathrm{L}$, respectively).

None of the patients who underwent revision surgery showed any signs of metallosis of the tissues surrounding the rods.

\section{Discussion}

AIS and arthroplasty literature suggest a systemic spread of the metals due to wear and tear of the implants [8-14]. One could argue that the metal release due to implantation would be lower in fusionless surgery because it comprises fewer implants and less intraoperative manipulation. Intersegmental motion might cause increased release due to wear as the implants sustain major load due to their fusionless nature. Moreover, additional metal ion release can be expected whilst repeated lengthenings $[15,16]$.

Titanium is also a micronutrient present in the body and majority of it is stored intracellularly [19]. Normal values for whole blood titanium levels in adult controls were 50-150 $\mu \mathrm{g} / \mathrm{L}$ according to Synlab/Leinfelden, Germany [19]. Cundy et al., Richardson et al. and Kasai et al. have proven that the serum concentrations of Titanium ion in patients with Titanium-based spinal implants have been found to be on the higher side as compared to those of controls [4-6]. Swiatkowska et al. [20] conclude in their study that due to inter-laboratory analytical differences, reliable conclusions regarding "normal" and "abnormal" titanium levels in patients with orthopaedic implants are difficult to draw. Diagnosis of symptomatic patients should be based on radiographic evidence combined with blood/serum metal levels. There are no studies that mention universally accepted normal values for serum titanium levels in paediatric patients. Aluminium, on the other hand, is an essential micronutrient in the human body and is ubiquitous in its distribution [4]. There is constant exposure to this element through ingestion of water and food and exposure to dust particles [4]. None of the patients in the present study showed any clinical symptoms that could be attributed to the raised titanium levels in the serum. None of the patients showed raised levels of aluminium ions in their serum samples consistent with 
Cundy et al. [4]. All the patients were residents of the same geographical region and hence were exposed to the same amount of non-implant-related metallic exposure. All the samples were tested in the same laboratory and all the storage and processing modalities were identical for all the samples. None of the patients that underwent revision surgeries for implant related complications such as broken rods or actuator dysfunction showed any signs of metallic staining of the surrounding tissues (metallosis).

In cohorts of pediatric patients with a mean postoperative time of 6 years after stainless steel spinal instrumentation, Kim et al. [9] and Cundy et al. [17] reported timedependent inverse relationships between serum metal levels (chromium) and time since spinal surgery. This "wearing-in" phenomenon has been attributed to the time taken for spinal fusion to occur (up to 24 months) and the associated decrease in micromotion between interfaces, which would limit wear and corrosion. The difference in our study is that the implant was not made of stainless steel but titaniumaluminium alloy. Whether titanium and aluminium levels also follow the above mentioned principle needs to be investigated. Patients with complications have shown elevated serum titanium levels compared to those without but whether these are clinically significant need to be determined. The levels of aluminium did not show any difference irrespective of presence or absence of complications. There is no linear correlation observed between the number of distractions or the number of anchor screws and the serum titanium and aluminium levels as can be seen in Table 2 . The assumption that more active children may generate more wear debris than non-ambulatory children is not consistent as seen in the study that non-ambulatory Rett syndrome and Cerebral palsy patients have shown elevated titanium levels as consistent with the more active idiopathic scoliosis subjects. (Table 1).

There are certain limitations of this study. Ideally speaking, the MCGR system is indicated for skeletally immature patients less than 10 years of age with progressive spinal deformity. All the patients included in the study were diagnosed before 10 years of age. The patients operated after 10 years of age were still skeletally immature (Risser grade 0-1) and the girls were premenarchal with significant growth potential at the time of surgery. No controls were used in this study to compare the blood levels of the titanium and aluminium ions. Also, epidemiological data stating the normal blood concentration of the titanium ions in this population are not available. The MCGR system is a titanium, aluminium, vanadium and niobium alloy. Laboratory testing of titanium and aluminium is widely available as compared to that for vanadium and niobium as vanadium and niobium are not as widely present in nature. Should the titanium and aluminium levels had pathologically increased, the authors would have utilized the resources for testing vanadium and niobium levels. This is a cross-sectional study with a small sample size that analysed a time-dependant event. Ideally, the preoperative, intraoperative and immediate postoperative serum samples of the patients in addition to the serial serum concentrations of the titanium and aluminium ions of each subject should have been studied. Our study fails to compare the postoperative serum titanium and aluminium concentrations with those preoperatively; and therefore falls short as compared to the findings of Yilgor et al. that there is a time-dependant increasing trend in the blood concentrations of metal ions in patients of early onset scoliosis treated with growth friendly instrumentation [18].

Further large-sized, prospective and long-term studies need to be designed to analyse the preoperative levels of titanium and aluminium ions and then compare these with the postoperative levels over a long term in a periodic manner to get an in depth analysis of the subject.

\section{Conclusion}

To conclude, implantation with magnetically controlled growing rod (MCGR) is accompanied by presence of titanium ions in the blood. The clinical significance of the same is yet to be determined. The serum aluminium levels tend to remain within normal limits. To our knowledge, the patients in our study have not shown any untoward clinical effects that could be attributed to the titanium levels in the serum. In addition, patients undergoing revision surgery for implant related complications such as broken rods or dysfunctional and broken actuators have not shown any signs of metallosis. Although, patients with broken rods and dysfunctional actuators have shown elevated serum titanium ion levels than those without these complications, determination of its clinical significance needs large-sized and long-term studies. There is no linear correlation between the number of anchor screws or the number of distractions and the serum titanium or aluminium concentrations.

Author Contribution All the authors whose names appear in the submission pledge that 1) Each author has made substantial contributions to the conceptualization of the work and also in the acquisition and analysis of the data. 2) Each author has drafted and revised the work critically for its intellectual content. 3) Each author approves the version to be published. 4) Each author agrees to be accountable for all the aspects of the work in ensuring that questions related to the accuracy or integrity of any part of the work are appropriately investigated and resolved. 5) Conceptualization (NH, SS); Methodology (BM, NH, SE); Formal analysis and investigation (SE, BM, CA); Writing- Original draft preparation (BM); Writing- review and editing (SS, NH, BM, CA); Resources (SE, SS, CA), Supervision (HN).

Funding No funding was received for this study from any sources. 


\section{Declarations}

Conflict of interest The authors declare that they have no conflict of interest.

Ethical approval The study was assigned 2019/20-59 as the reference number by the Institutional Ethical Committee at the Royal National Orthopaedic Hospital, Stanmore.

Consent to participate An informed consent was obtained from all the patients and their parents/legal guardians for participation in the study.

Consent to publish All the patients and their parents/legal guardians consented for the data to be published.

Open Access This article is licensed under a Creative Commons Attribution 4.0 International License, which permits use, sharing, adaptation, distribution and reproduction in any medium or format, as long as you give appropriate credit to the original author(s) and the source, provide a link to the Creative Commons licence, and indicate if changes were made. The images or other third party material in this article are included in the article's Creative Commons licence, unless indicated otherwise in a credit line to the material. If material is not included in the article's Creative Commons licence and your intended use is not permitted by statutory regulation or exceeds the permitted use, you will need to obtain permission directly from the copyright holder. To view a copy of this licence, visit http://creativecommons.org/licenses/by/4.0/.

\section{References}

1. Akbarnia BA, Cheung K, Noordeen H (2013) Next generation of growth sparing techniques: preliminary clinical results of a magnetically controlled growing rod in 14 patients with early-onset scoliosis. Spine 38:665-670

2. Dannawi Z, Altaf F, Harshavardhana N, Sebaie H, Noordeen H (2013) Early results of a remotely-operated magnetic growth rods in early-onset scoliosis. J Bone Jt Surg Br 95B:75-80

3. Akbarnia BA, Campbell RM, Dimeglio A et al (2011) Fusionless procedures for the management of early-onset spine deformities in 2011: what do we know? J Child Orthop 5:159e72

4. Cundy TP, Antoniou G, Sutherland LM et al (2013) Serum titanium, niobium, and aluminum levels after instrumented spinal arthrodesis in children. Spine 38:564e70

5. Kasai Y, Iida R, Uchida A (2003) Metal concentrations in the serum and hair of patients with titanium alloy spinal implants. Spine 28:1320-1326

6. Richardson TD, Pineda SJ, Strenge KB, Van Fleet TA, MacGregor M, Milbrandt JC et al (2008) Serum titanium levels after instrumented spinal arthrodesis. Spine 33:792-796
7. Botolin S, Merritt C, Erickson M (2013) Aseptic loosening of pedicle screw as a result of metal wear debris in a pediatric patient. Spine 38:E38-E42

8. Cundy WJ, Mascarenhas AR, Antoniou G et al (2015) Local and systemic metal ion release occurs intraoperatively during correction and instrumented spinal fusion for scoliosis. J Child Orthop 9:39e 43

9. Kim YJ, Kassab F, Berven SH et al (2005) Serum levels of nickel chromium after Instrumented posterior spinal arthrodesis. Spine 30:923e6

10. Richardson TD, Pineda SJ, Strenge KB et al (2008) Serum titanium levels after instrumented spinal arthrodesis. Spine 33:792e6

11. Savarino L, Greggi T, Martikos K et al (2015) Long-term systemic metal distribution in patients with stainless steel spinal instrumentation: a case-control study. J Spinal Disord Tech 28:114e8

12. Savarino L, Granchi D, Ciapetti G et al (2002) Ion release in patients with metal-on-metal hip bearings in total joint replacement: a comparison with metal-on-polyethylene bearings. J Biomed Mater Res 63:467e74

13. Engh CA Jr, MacDonald SJ, Sritulanondha S et al (2009) 2008 John Charnley award: metal ion levels after metal-on-metal total hip arthroplasty: a randomized trial. Clin Orthop Relat Res 467:101e11

14. Engh CA, MacDonald SJ, Sritulanondha S et al (2014) Metal ion levels after metal-on-metal total hip arthroplasty: a five-year, prospective randomized trial. J Bone Jt Surg Am 96:448e55

15. Agarwal A, Agarwal AK, Jayaswal A et al (2017) Outcomes of optimal distraction forces and frequencies in growth rod surgery for different types of scoliotic curves: an in silico and in vitro study. Spine Deform. 5:18e26

16. Galvis S, Arnold J, Mannen E et al (2017) Biomechanical evaluation of a growth-friendly rod construct. Spine Deform 5:11e7

17. Cundy TP, Delaney CL, Rackham MD et al (2010) Chromium ion release from stainless steel pediatric scoliosis instrumentation. Spine (Phila Pa 1976) 35:967-974

18. Yilgor C, Efendiyev A, Akbiyik F et al (2018) Metal ion release during growth-friendly instrumentation for early-onset scoliosis: a preliminary study. Spine Deform 6:48-53

19. Ipach I, Schafer R, Mittag F et al (2012) The development of whole blood titanium levels after instrumented spinal fusion-Is there a correlation between the number of fused segments and titanium levels? BMC Musculoskelet Disord 13:159

20. Swiatkowska I, Martin N, Hart AJ (2019) Blood titanium level as a biomarker of orthopaedic implant wear. J Trace Elem Med Biol 53:120-128. https://doi.org/10.1016/j.jtemb.2019.02.013

Publisher's Note Springer Nature remains neutral with regard to jurisdictional claims in published maps and institutional affiliations. 